\title{
Effect of Vermicompost on Chemical and Biological Properties of an Alkaline Soil with High Lime Content during Celery (Apium graveolens L. var. dulce Mill.) Production
}

\author{
Ilker UZ ${ }^{1 *}$, Sahriye SONMEZ ${ }^{1}$, Ismail Emrah TAVALI ${ }^{1}$, Sedat CITAK $^{1,3}$, \\ Dilek Saadet URAS ${ }^{1,4}$, Sevil CITAK ${ }^{2}$ \\ ${ }_{1}^{1}$ Akdeniz University, Faculty of Agriculture,DepartmentofSoil ScienceandPlantNutrition,Antalya, Tunkey; ilkeruz@akdenizedu.tr (*correspondingauthor); \\ ssonmez@akdenizedu.tr; etavali@akdenizedu.tr;scitak@hotmail.com;dsuras@akdeniz.edu.tr \\ 2AkdenizUniversity,_Kumluca VocationalSchool,07350Kumluca,Antalya,Tunkey;scitak@akdenizedu.tr \\ 3Present address: Magro Tarim A.S., 35470 Menderes, Izmir, Turkey \\ ${ }^{4}$ Present address: Akdeniz University, Korkuteli Vocational School, 07080 Korkuteli, Antalya, Turkey
}

\begin{abstract}
The aim of this study was to investigate impact of vermicompost on chemical and biological properties of an alkaline soil with high lime content in the presence of plant under the open field conditions in semiarid Mediterranean region of Turkey. The study also included farmyard manure and chemical fertilizers for comparison and was conducted in two consecutive growth seasons in the same plots to observe any cumulative effect. Plots were amended with fertilizers in different rates and celery (Apium graveolens L. var. dulce Mill.) was grown as the test plant. In general, vermicompost appeared to be more effective to increase organic matter, N, P, and Ca compared to farmyard manure. Soil alkaline phosphatase and $\beta$-glucosidase activities, especially in the second growth season, were significantly elevated by the vermicompost application. Urease activity, however, appeared not to be influenced by the type of organic fertilizer. A slight but statistically significant difference was detected between organic amendments in terms of number of aerobic mesophilic bacteria with vermicompost giving the lower values. Results showed that, in general, vermicompost significantly alters chemical and biological properties of the alkaline soil with high lime content during celery production under field conditions compared to farmyard manure and that it has a high potential to be used as an alternative to conventional organic fertilizers in agricultural production in the Mediterranean region of Turkey.
\end{abstract}

Keywords: bacterial enumeration, calcareous soil, cumulative effect, soil enzyme activity, organic farming

\section{Introduction}

It is highly recommended to use organic fertilizers in agricultural production to supply soils with plant nutrients and improve soil chemical, physical, and biological properties (Brady and Weil, 2001). Conventional fertilizers such as farmyard manure and compost are widely used for these purposes (Ferreras et al., 2006; Herencia et al., 2007). However, in recent years, vermicompost has been emerged as an alternative to conventional organic fertilizers due to its additional benefits. Vermicompost, which is the product of nonthermophilic biodegradation of organic material through the joint action of earthworms and microorganisms, contains plant growth promoting compounds and exhibits disease suppression properties in addition to being nutrient source and soil conditioner (Logsdon, 1994; Ersahin et al., 2009). Some problems, such as nutrient loss, nutrient toxicity, and salinity that may be associated with organic amendments under certain conditions could also be avoided by vermicompost application due to more gradual release of nutrients from vermicompost to the soil environment (Kale et al., 1987; Nethra et al., 1999; Lazcano et al., 2008).

Vermicompost has been the subject of several studies related to its utilization in agriculture. The main objectives in majority of these studies have been its disease suppression properties (Ersahin et al., 2009; Somasekhara et al., 2011; Singh et al., 2012; Carr and Nelson, 2014) and its effect on plant growth and yield (Arancon et al., 2003; Sallaku et al., 2009; Kalantari et al., 2011). There are also some studies focusing on the relationship between vermicompost and soil biological and chemical properties under various soil conditions (Arancon et al., 2006; Gopinath et al., 2011; Tejada and Benitez, 2011; Doan et al., 2013; Lazcano et al., 2013; Doan et al., 2014). However, most of these studies employed soils with neutral or acidic reactions. Therefore, in terms of soil biological and chemical 
parameters, how vermicompost performs in alkaline soils with high lime content is open to speculation due to lack of information. Moreover, in general, such studies involve short-term experimentation and soil sampling in limited frequency. As we noted in a previous study (Uz and Tavali, 2014), in order to assess cumulative effect of vermicompost and true nature of relationships, experiments should be repeated in the same blocks in consecutive growth seasons with presence of plants under the open field conditions. In such studies, more frequent soil sampling should be employed to monitor microbial changes in detail after application of vermicompost. This is especially important for Turkish Mediterranean region whose soils are typically in alkaline character with high lime content. Even though there are some studies investigating potential of vermicompost for plant growth and yield in the region (Tavali et al., 2013; Kucukyumuk et al., 2014), to our knowledge, there is no detailed study focusing on the effect of vermicompost on biological and chemical properties of soil in this region.

Therefore, the aim of this study was to investigate effect of vermicompost on some chemical and biological properties of alkaline soil with high lime content during celery production in two consecutive growth periods under the open field conditions in the semiarid Mediterranean region of Turkey.

\section{Materials and Methods}

\section{Study area, organic and biological materials}

This study was conducted as a field experiment in training and application land of Faculty of Agriculture at Akdeniz University located on Antalya, Turkey (Fig. 1A). Vermicompost used in the study was produced mainly from farmyard manure and provided by a local company, and farmyard manure was obtained from the dairy farm belonging to the Faculty of Agriculture. Celery (Apium graveolens L. var. dulce Mill) was used as the test plant.

\section{Experimental design and data collection}

The study conducted under field conditions with randomized factorial block design with four replicates and contained 56 plots and 30 plants in each plot (Fig. 1B). The experiment was repeated in two consecutive growth seasons (Fall-2011 and Spring-2012) in
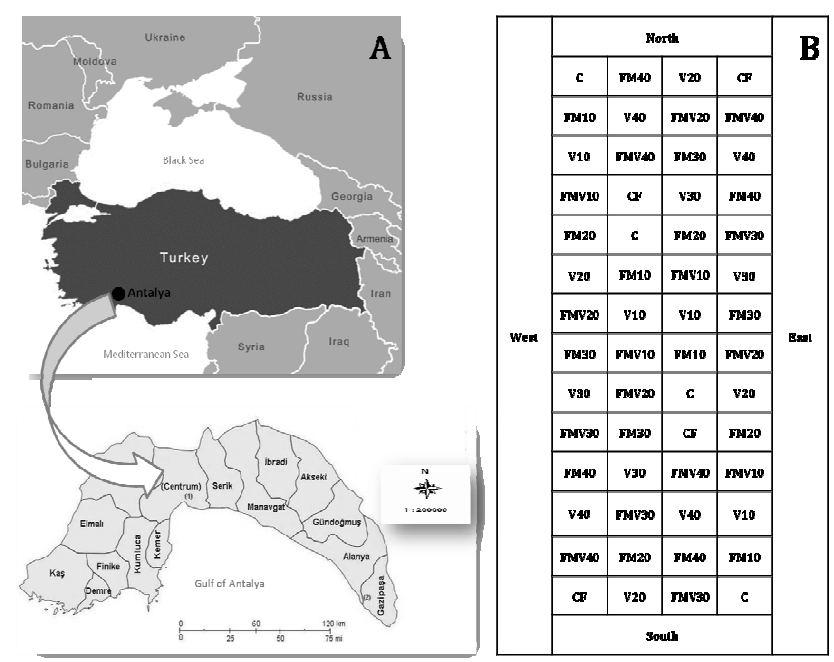

Fig. 1. Location of the study area (A) and experimental design (B) the same plots and each season lasted approximately 100-120 days after transplantation. The study included two organic materials (vermicompost $[\mathrm{V}]$ and farmyard manure $[\mathrm{FM}]$ ) applied in five different doses and three combinations. Also, a treatment with chemical fertilizers corresponding to amount of nutrients taken up by celery plants from soil $\left(180 \mathrm{kgha}^{-1} \mathrm{~N}, 100 \mathrm{kgha}^{-1} \mathrm{P}_{2} \mathrm{O}_{5}\right.$, and 180 $\mathrm{kg} \mathrm{ha}{ }^{-1} \mathrm{~K}_{2} \mathrm{O}$ ) was included (Vural et al., 2000). Application rates and treatments are given in Table 1. Prior to the experiment, physical, chemical and biological properties of test soil and organic fertilizers were determined (Table 2). Also, at the end of the experiment in each growth season (Fall and Spring) soil samples from each block were collected and analyzed for $\mathrm{pH}$, electrical conductivity (EC), organic matter content, total $\mathrm{N}$, available $\mathrm{P}$, exchangeable $\mathrm{K}, \mathrm{Ca}$, and $\mathrm{Mg}$ contents. In order to assess the effect of organic materials on soil biological properties, soil samples were collected in regular intervals $(0,1 \mathrm{st}, 2 \mathrm{nd}$, 3th, 4th, 6th, 10th, 13th, and 18 th week) from plots receiving organic fertilizers in the rates of 0, 20 and $40 \mathrm{tha}^{-1}$ (C, FM20, V20, FM40, V40) and blocks treated with chemical fertilizers $(\mathrm{CF})$ and analyzed for biological parameters. Biological parameters measured included urease, alkaline phosphatase and $\beta$-glucosidase activities, and total number of aerobic mesophilic bacteria in soil. Soil pH and EC were also monitored.

\section{Methods}

Soil texture was determined by using Bouyoucos hydrometer method (Bouyoucos, 1951). Soil pH and EC were measured in 1:2.5 soil-water mixture (Jackson, 1970; Rhoades, 1982). Soil lime content was analyzed according to Caglar (1949). Soil organic matter content was measured by using modified Walkley-Black method (Nelson and Sommers, 1982) and total $\mathrm{N}$ by modified Kjheldahl method (Bremner and Mulvaney, 1982). Analysis of available phosphorus content of soil samples was done as described by Olsen and Sommers (1982). Exchangeable $\mathrm{K}, \mathrm{Ca}$, and $\mathrm{Mg}$ contents were determined by ammonium acetate method (Kacar, 1994) and available Fe, Mn, $\mathrm{Zn}$, and Cu by DTPA method (Lindsay and Norvell, 1978) using ICP-OES (PE Optima 7000DV). Values of $\mathrm{pH}, \mathrm{EC}$, organic matter and total $\mathrm{N}$ contents of organic materials were determined with the same methods used for soil samples. For total $\mathrm{P}, \mathrm{K}, \mathrm{Ca}, \mathrm{Mg}, \mathrm{Fe}, \mathrm{Zn}, \mathrm{Mn}$, and $\mathrm{Cu}$ contents of the organic fertilizers, samples were wet-digested (4:1 HNO3:HClO4) and measured with ICP-OES (Soltanpour and Workman, 1981). Soil enzyme activities were measured as described by Tabatabai

Table 1. Application rates and treatments used in the study

\begin{tabular}{|c|c|}
\hline $\begin{array}{l}\text { Application } \\
\text { rate }\end{array}$ & Treatment \\
\hline 0 tha $^{-1}$ & Control $(\mathrm{C})$ \\
\hline \multirow{3}{*}{$10 \mathrm{t} \mathrm{ha}^{-1}$} & $100 \%$ Farmyard Manure (FM10) \\
\hline & $100 \%$ Vermicompost (V10) \\
\hline & $50 \%$ Farmyard Manure $+50 \%$ Vermicompost (FMV10) \\
\hline \multirow{3}{*}{$20 \mathrm{t} \mathrm{ha}^{-1}$} & $100 \%$ Farmyard Manure (FM20) \\
\hline & $100 \%$ Vermicompost (V20) \\
\hline & $50 \%$ Farmyard Manure $+50 \%$ Vermicompost (FMV20) \\
\hline \multirow{3}{*}{$30 \mathrm{t} \mathrm{ha}^{-1}$} & $100 \%$ Farmyard Manure (FM30) \\
\hline & $100 \%$ Vermicompost (V30) \\
\hline & $50 \%$ Farmyard Manure $+50 \%$ Vermicompost (FMV30) \\
\hline \multirow{3}{*}{$40 \mathrm{t} \mathrm{ha}^{-1}$} & $100 \%$ Farmyard Manure (FM40) \\
\hline & $100 \%$ Vermicompost (V40) \\
\hline & $50 \%$ Farmyard Manure + 50\% Vermicompost (FMV40) \\
\hline $\begin{array}{l}\text { Chemical } \\
\text { Fertilizer }\end{array}$ & N-P-K: $15-15-15$ (CF) \\
\hline
\end{tabular}


Table 2. Physical, chemical and biological properties of soil and organic materials used in the study

\begin{tabular}{|c|c|c|c|c|}
\hline Parameters & Soil & Parameters & Vermicompost & $\begin{array}{c}\text { Farmyard } \\
\text { manure }\end{array}$ \\
\hline Texture & Clay & Texture & - & - \\
\hline $\mathrm{pH}(1: 2.5$ water $)$ & 7.90 & $\mathrm{pH}(1: 2.5$ water $)$ & 7.73 & 7.98 \\
\hline EC (1:2.5 soil:water $) \mu \mathrm{cm}^{-1}$ & 265 & EC $(1: 2.5$ soil:water $) \mu \mathrm{cm}^{-1}$ & 1558 & 4325 \\
\hline Lime (\%) & 6.25 & Lime (\%) & - & - \\
\hline Organic matter (\%) & 1.51 & Organic matter $(\%)$ & 51.23 & 65.98 \\
\hline Total N (\%) & 0.09 & Total N (\%) & 1.88 & 1.51 \\
\hline $\mathrm{C} / \mathrm{N}$ & $9 / 1$ & $\mathrm{C} / \mathrm{N}$ & $15 / 1$ & $25 / 1$ \\
\hline Available $\mathrm{P}\left(\mathrm{mg} \mathrm{kg}^{-1}\right)$ & 9.23 & Total P (\%) & 1.98 & 0.83 \\
\hline Exchangeable $\mathrm{K}\left(\mathrm{mg} \mathrm{kg}^{-1}\right)$ & 254 & Total K (\%) & 0.85 & 2.39 \\
\hline Exchangeable $\mathrm{Ca}\left(\mathrm{mg} \mathrm{kg}^{-1}\right)$ & 4081 & Total $\mathrm{Ca}(\%)$ & 2.28 & 2.79 \\
\hline Exchangeable $\mathrm{Mg}\left(\mathrm{mg} \mathrm{kg}^{-1}\right)$ & 151 & Total $\mathrm{Mg}(\%)$ & 0.91 & 0.69 \\
\hline Available $\mathrm{Fe}\left(\mathrm{mg} \mathrm{kg}^{-1}\right)$ & 2.6 & Total Fe (\%) & 0.14 & 0.05 \\
\hline Available $\mathrm{Mn}\left(\mathrm{mg} \mathrm{kg}^{-1}\right)$ & 4.95 & Total Mn (\%) & 0.04 & 0.006 \\
\hline Available $\mathrm{Zn}\left(\mathrm{mg} \mathrm{kg}^{-1}\right)$ & 0.6 & Total Zn (\%) & 0.01 & 0.05 \\
\hline Available $\mathrm{Cu}\left(\mathrm{mg} \mathrm{kg}^{-1}\right)$ & 0.11 & Total Cu (\%) & 0.005 & 0.006 \\
\hline Urease $\left(\mu \mathrm{g} \mathrm{NH}_{4}^{+}-\mathrm{N} \mathrm{g}^{-1} \mathrm{dw} \mathrm{h}^{-1}\right)$ & 12.86 & Urease $\left(\mu \mathrm{g} \mathrm{NH}_{4}^{+}-\mathrm{N} \mathrm{g}^{-1} \mathrm{dw} \mathrm{h}^{-1}\right)$ & 119.52 & 146.96 \\
\hline $\begin{array}{l}\text { Alkaline phosphatase } \\
\left(\mu \mathrm{g} \text { PNP g }^{-1} \mathrm{dw} \mathrm{h}^{-1}\right)\end{array}$ & 28.91 & $\begin{array}{l}\text { Alkaline phosphatase } \\
\left(\mu \mathrm{g} \text { PNP g } \mathrm{d}^{-1} \mathrm{dw}^{-1}\right)\end{array}$ & 277.76 & 198.26 \\
\hline $\begin{array}{l}\beta \text {-glucosidase } \\
\left(\mu \mathrm{gNG} \mathrm{g}^{-1} \mathrm{dw} \mathrm{h}^{-1}\right)\end{array}$ & 6.98 & $\begin{array}{c}\beta \text {-glucosidase } \\
\left(\mu \mathrm{g} P \mathrm{PN}^{-1} \mathrm{dw} \mathrm{h}^{-1}\right)\end{array}$ & 87.92 & 92.66 \\
\hline $\begin{array}{l}\text { Number of aerobic mesophilic bacteria } \\
\left(\mathrm{cfu} \mathrm{g}^{-1} \mathrm{dw}\right)\end{array}$ & $1.0 \times 10^{6}$ & $\begin{array}{l}\text { Number of aerobic mesophilic bacteria } \\
\left(\mathrm{cfu} \mathrm{g}^{-1} \mathrm{dw}\right)\end{array}$ & $1.7 \times 10^{7}$ & $1.8 \times 10^{7}$ \\
\hline
\end{tabular}

(1994). Total number of aerobic mesophilic bacteria was determined by using dilution plate count method and expressed as cfu g ${ }^{-1}$ dry weight soil (Parkinson et al., 1971).

\section{Statistical analysis}

In order to determine similarities and differences among treatments, data obtained from the study were subjected to statistical analysis including ANOVA for soil chemical parameters and repeated measure ANOVA (rANOVA) for biological parameters, $\mathrm{pH}$ and EC. Duncan multiple range test and Pearson correlation tests were also performed. All statistical analysis was done by using SPSS package program (SPSS, 2008).

\section{Results and Discussion}

\section{Organicmatter}

Organic matter contents of soil samples from treatments at the end of the growth seasons are given in Table 3. In both growth seasons, soil organic matter content was significantly affected by organic amendments compared to the control $(p<0.001)$. In the first season, the lowest and highest organic matter content values were obtained with the control and FMV40 treatments, respectively. In the second season, lowest and highest values were with the control and FMV20 treatments, respectively. Organic fertilizers increased the soil organic matter content depending on application rates compared to the control. Moreover, vermicompost was found to increase organic matter more than farmyard manure applied in the same doses (except for FM40 and $\mathrm{V} 40$ in the first season and FM20 and V20 in the second season). There also appeared to be a difference between seasons and the second season showed higher organic matter content.

It was reported that applications of organic materials in increasing rates result in elevated soil organic matter content (Ferreras et al., 2006; Ouda and Mahadeen, 2008). Therefore, observing similar results in our study is not surprising. The difference between the first and the second season in terms of organic matter content in soil can be explained by the difference in weather conditions affecting degradation processes. Due to cooler weather in the first season, it is possible that activity of microorganisms was limited and, therefore, some of organic compounds added with fertilizers might have remained unchanged at the end of the season. In the second season, however, with warmer weather, remaining and newly added organic compounds might have been decomposed in faster rate elevating soil organic matter content. The data suggest that vermicompost is more effective than farmyard manure to increase soil organic matter content even though farmyard manure used in the study has higher organic matter (Table 2). This is rather interesting because our previous study conducted with a similar soil under laboratory conditions without plants showed no significant difference between these two materials in terms of soil organic matter content (Uz and Tavali, 2014). Cheng et al. (2003) reported that decomposition rate in soils with plant is significantly higher than that in soils with no plants. Therefore, it is possible to suggest that, under field condition, presence of plants enhances effect of vermicompost on organic matter content. As a result, vermicompost may be considered as a better alternative than farmyard manure under field conditions in terms of improving organic matter in this soil. Indeed, several researchers support this conclusion (Kale et al., 1987; Nethra et al., 1999; Azarmi et al., 2008; Lazcano et al., 2008).

\section{Total $N$, available $P$ and exchangeable $K$}

Total N, available P and exchangeable K contents of soils at the end of the growth seasons are shown in Table 3. In general, significant increases in these nutrients were observed with increasing application doses $(\mathrm{p}<0.001)$. Total $\mathrm{N}$ contents of treatment soils in the first season ranged from $0.13 \%$ to $0.18 \%$ and were found to be highly close to each other even though differences among treatments are significant. In the second season, however, 
Table 3. Effect of treatments on soil chemical properties at the end of growth seasons

\begin{tabular}{|c|c|c|c|c|c|c|c|c|c|c|c|c|}
\hline \multirow{3}{*}{ Treatment } & \multicolumn{2}{|c|}{$\begin{array}{c}\text { Organic matter } \\
(\%)\end{array}$} & \multicolumn{2}{|c|}{$\begin{array}{c}\text { Total N } \\
(\%)\end{array}$} & \multicolumn{2}{|c|}{$\begin{array}{c}\text { Available P } \\
\left(\mathrm{mg} \mathrm{kg}^{-1}\right)\end{array}$} & \multicolumn{2}{|c|}{$\begin{array}{c}\text { Exchangeable } \mathrm{K} \\
\left(\mathrm{mg} \mathrm{kg}^{-1}\right)\end{array}$} & \multicolumn{2}{|c|}{$\begin{array}{c}\text { Exchangeable Ca } \\
\left(\mathrm{mg} \mathrm{kg}^{-1}\right)\end{array}$} & \multicolumn{2}{|c|}{$\begin{array}{c}\text { Exchangeable } \mathrm{Mg} \\
\left(\mathrm{mg} \mathrm{kg}^{-1}\right)\end{array}$} \\
\hline & \multicolumn{12}{|c|}{ Growth Season } \\
\hline & I & II & I & II & I & II & I & II & I & II & I & II \\
\hline $\mathrm{C}$ & $2.13 \mathrm{j}^{1}$ & $1.84 \mathrm{~g}$ & $0.13 c$ & $0.12 c$ & $31.9 \mathrm{~h}$ & $52.0 \mathrm{~g}$ & $174 \mathrm{~b}$ & $247 f$ & $3328 b$ & $3460 \mathrm{c}$ & $210 c$ & $260 \mathrm{f}$ \\
\hline FM10 & 2.241 & $2.34 \mathrm{f}$ & $0.15 b$ & $0.13 c$ & $41.7 \mathrm{~h}$ & $56.2 \mathrm{f}$ & $176 b$ & $338 \mathrm{e}$ & $3282 b$ & $3338 \mathrm{~d}$ & $216 c$ & $267 \mathrm{f}$ \\
\hline V10 & $2.33 \mathrm{~h}$ & $3.26 \mathrm{~d}$ & $0.13 c$ & $0.16 c$ & $52.6 \mathrm{~g}$ & $64.3 \mathrm{e}$ & $205 b$ & $351 \mathrm{e}$ & $3328 b$ & $3570 \mathrm{~b}$ & $217 \mathrm{c}$ & $297 \mathrm{~d}$ \\
\hline FMV10 & $2.35 \mathrm{~h}$ & $2.54 \mathrm{f}$ & $0.14 \mathrm{c}$ & $0.13 c$ & $33.5 \mathrm{~h}$ & $65.3 \mathrm{e}$ & $228 \mathrm{~b}$ & $366 \mathrm{e}$ & $3638 a$ & $3762 b$ & $235 b$ & $284 \mathrm{e}$ \\
\hline FM20 & $2.43 \mathrm{~g}$ & $3.41 \mathrm{~d}$ & $0.13 c$ & $0.13 c$ & $67.5 \mathrm{f}$ & $62.0 \mathrm{e}$ & $177 \mathrm{~b}$ & $468 \mathrm{~d}$ & $2900 \mathrm{c}$ & $3260 \mathrm{e}$ & $196 \mathrm{~d}$ & $258 \mathrm{f}$ \\
\hline V20 & $2.54 \mathrm{e}$ & $3.70 \mathrm{c}$ & $0.15 b$ & $0.21 b$ & $52.9 \mathrm{~g}$ & $120 \mathrm{a}$ & $210 \mathrm{~b}$ & $586 \mathrm{~b}$ & $3234 b$ & $3454 c$ & $222 c$ & $357 \mathrm{~b}$ \\
\hline FMV20 & $2.53 \mathrm{e}$ & $4.09 a$ & $0.16 b$ & $0.20 \mathrm{~b}$ & $82.8 \mathrm{e}$ & $82.2 \mathrm{~d}$ & $205 b$ & $560 b$ & $3186 c$ & $3656 b$ & $216 c$ & $342 b$ \\
\hline FM30 & $2.45 \mathrm{f}$ & $3.16 \mathrm{~d}$ & $0.17 \mathrm{a}$ & $0.18 b$ & $62.6 \mathrm{f}$ & $74.6 \mathrm{~d}$ & $235 a$ & $584 b$ & $3172 \mathrm{c}$ & $3504 b$ & $212 c$ & $310 \mathrm{c}$ \\
\hline V30 & $2.77 \mathrm{~d}$ & $3.12 \mathrm{~d}$ & $0.15 b$ & $0.23 a$ & $95.4 \mathrm{c}$ & $104 \mathrm{~b}$ & $249 a$ & $510 c$ & $3388 b$ & $3678 b$ & $240 a$ & $333 b$ \\
\hline FMV30 & $2.85 c$ & $3.85 \mathrm{~b}$ & $0.18 \mathrm{a}$ & $0.18 b$ & 105.b & $79.7 \mathrm{~d}$ & $234 \mathrm{a}$ & $534 c$ & $3188 \mathrm{c}$ & $3600 \mathrm{~b}$ & $223 c$ & $330 \mathrm{~b}$ \\
\hline FM40 & $3.08 \mathrm{a}$ & $2.94 \mathrm{e}$ & $0.17 \mathrm{a}$ & $0.23 a$ & $69.8 \mathrm{f}$ & $68.5 \mathrm{e}$ & $260 \mathrm{a}$ & $611 b$ & $3336 b$ & $3438 c$ & $226 c$ & $322 c$ \\
\hline V40 & $3.01 \mathrm{~b}$ & $3.65 c$ & $0.18 \mathrm{a}$ & $0.23 a$ & $113.1 \mathrm{a}$ & $113 a$ & $215 b$ & $592 b$ & $3192 c$ & $3472 c$ & $225 c$ & $337 \mathrm{~b}$ \\
\hline FMV40 & $3.08 \mathrm{a}$ & $3.53 \mathrm{~d}$ & $0.17 \mathrm{a}$ & $0.24 a$ & $113.4 \mathrm{a}$ & $93.1 \mathrm{c}$ & $246 a$ & $734 a$ & $3064 c$ & $3814 a$ & $216 c$ & $360 a$ \\
\hline CF & $2.95 \mathrm{~b}$ & $1.98 \mathrm{f}$ & $0.13 c$ & $0.19 b$ & $85.6 \mathrm{~d}$ & $60.3 \mathrm{f}$ & $225 b$ & $391 \mathrm{e}$ & $3030 \mathrm{c}$ & $3824 a$ & $206 \mathrm{~d}$ & $255 \mathrm{f}$ \\
\hline LSD $\% 5$ & $* * * 2$ & *** & *** & $* * *$ & $* * *$ & *** & *** & *** & $* 3$ & *** & * & $* * *$ \\
\hline
\end{tabular}

${ }^{\mathrm{T}}$ Means in the same column followed by the same letter are not significantly different. ${ }^{2 * * *} \mathrm{p}<0.001$.

${ }^{3 *} \mathrm{p}<0.05$.

the differences among treatments are more prominent $(\mathrm{p}<0.001)$. Total $\mathrm{N}$ contents of soils varied between $0.12 \%$ and $0.24 \%$ and appeared to be higher than those of the first season. Based on the values from blocks receiving vermicompost and farmyard manure in the same doses (except for FM40 and V40) vermicompost increased total $\mathrm{N}$ more effectively than farmyard manure. Application of fertilizers also significantly affected available $\mathrm{P}$ contents of soils $(p<0.001)$ in both growth seasons. Available P values ranged between $31.9 \mathrm{ppm}$ and $113.4 \mathrm{ppm}$ in the first season and $52.2 \mathrm{ppm}$ and $120.3 \mathrm{ppm}$ in the second season. Similar to total $\mathrm{N}$, vermicompost was observed to increase available $\mathrm{P}$ concentration more than farmyard manure applied in the same doses. In addition, available $\mathrm{P}$ in some of the treatment soils, especially the treatments receiving chemical fertilizer $(\mathrm{CF})$ and combination of farmyard manure and vermicompost (FMV), decreased or remained unchanged in the second season compared to the first season. Effect of amendments on soil exchangeable $\mathrm{K}$ contents in both growth seasons was found to be statistically significant compared to the control $(\mathrm{p}<0.001)$. In the first season, vermicompost applied in the rate of 10 and $20 \mathrm{tha}^{-1}$ (V10 and V20) appeared to elevate soil exchangeable $\mathrm{K}$ content while no significant change was observed with farmyard manure applied in the same rates. When the application rate was increased to 30 and $40 \mathrm{tha}^{-1}$ (V30 and V40), however, vermicompost resulted in similar or lower $\mathrm{K}$ values than did farmyard manure. In the second season, exchangeable $\mathrm{K}$ contents of all treatment soils increased compared to the first season and the differences among treatments in this season were found to be significant $(p<0.001)$. Except for FM20 and V20 treatments, vermicompost amendments gave similar or slightly but significantly lower $\mathrm{K}$ values compared to the farmyard manure amendments.

When organic materials are applied to soils to improve organic matter status, they also supply soils with nutrients including $\mathrm{N}, \mathrm{P}$ and K (Tiwari et al,, 2004; Zakir et al., 2012). Our data are in agreement with this fact. Vermicompost that we used had higher total $\mathrm{N}$ and available $\mathrm{P}$ than those of farmyard manure. This may explain higher total $\mathrm{N}$ and available $\mathrm{P}$ values in soils treated with vermicompost compared to the soils with farmyard manure. On the other hand, these findings contradict some previous reports suggesting that especially phosphorus in vermicompost is released more gradually in available form in soil (Kale et al., 1987; Doube and Brown, 1998; Nethra et al., 1999; Lazcano et al., 2008). Our previous study showing similar total $\mathrm{N}$ and available $\mathrm{P}$ contents in soils with vermicompost and farmyard manure supported these reports (Uz and Tavali, 2014). Based on our current data, it appears that this remark does not always apply. Some factors including weather conditions, soil type, presence of plants and plant type may influence rate of nutrient release from vermicompost. K content of farmyard manure used in our study was almost three times higher than that of vermicompost (Table 2). As a result, soils receiving farmyard manure especially in high doses showed higher level of exchangeable $\mathrm{K}$ compared to the soils with vermicompost applied in the same doses. The difference between K concentrations of vermicompost and farmyard manure is rather interesting because, in general, $\mathrm{K}$ concentration ranges between 0.8 and $1.2 \%$ in farmyard manure and 1.4 and $2.0 \%$ in vermicompost (Agarwal, 1999). On the other hand, in our previous study (Uz and Tavall, 2014), vermicompost and farmyard manure obtained from the same company and dairy farm showed a similarly significant difference in $\mathrm{K}$ concentration. Therefore, even though vermicompost used in the present study is produced from farmyard manure, nutrient composition and quality of the source material and vermicomposting conditions may greatly affect nutrient content of the vermicompost. Similary, nutrient content of farmyard manure may be influenced by cattle feeding practices and cattle dung maturation conditions. There are several reports in scientific literature indicating that farmyard manure and vermicompost enrich soils in terms of major plant nutrients (Patil and Sheelavantar, 2006; Gopinath et al., 2009; Pant et al., 2011; Doan et al., 2014; Sharma and Banik, 2014). Our findings are in agreement with these reports but also suggest that vermicompost may be considered as a better alternative than farmyard manure, especially in terms of $\mathrm{N}$ and $\mathrm{P}$ addition, in alkaline soils of Mediterranean region of Turkey.

\section{Exchangeable $\mathrm{Ca}, \mathrm{Mg}$}

Exchangeable $\mathrm{Ca}$ and $\mathrm{Mg}$ contents of soils at the end of the growth seasons are provided in Table 3. Effect of treatments on exchangeable Ca content of soils was found to be significant in the first and second growth seasons $(\mathrm{p}<0.05$ and $\mathrm{p}<0.001$, 
284

respectively). In the first season, application of organic materials (except for AGV10) resulted in similar or lower Ca concentrations in soil compared to the control. In the second season, in general, exchangeable $\mathrm{Ca}$ concentrations exhibited an increasing trend according to the application doses and were higher than their counterparts were in the first season in all treatments. In both growth seasons, soils receiving vermicompost gave higher Ca values than did soils with farmyard manure in the same doses (except for FM40 and V40). Soil exchangeable Mg content was significantly affected by treatments in the first and second growth seasons $(\mathrm{p}<0.05$ and $\mathrm{p}<0.001$, respectively). Unlike exchangeable $\mathrm{Ca}, \mathrm{Mg}$ values in soils treated with fertilizers were generally above the control value (except for AG20 and CF) in the first season. In this season, the treatments with vermicompost showed similar or slightly higher $\mathrm{Mg}$ values compared to the farmyard manure treatments. In the second season, however, difference between vermicompost and farmyard manure treatments was more prominent. Mg values in all treatments were higher than those of the first season and effect of application in increasing rate was more apparent.

It is known that organic amendments improve soil cation exchange capacity (CEC) through humus formation and increase concentrations of nutrients such as $\mathrm{Ca}$ and $\mathrm{Mg}$ as a result of decomposition (Jenkinson, 1990; Johnston, 1997). Storage and availability of these cations in soil is closely related to CEC. Therefore, an increase in exchangeable $\mathrm{Ca}$ and $\mathrm{Mg}$ contents in soils with organic fertilizers are expected. However, in the first season, similar or lower $\mathrm{Ca}$ values in soils with fertilizers compared to the control and significant but small differences in $\mathrm{Mg}$ contents among treatments may indicate effect of some other factors. Indeed, elevated $\mathrm{Ca}$ and $\mathrm{Mg}$ values in the second season in all treatments including the control and CF, which did not receive organic materials, provide evidence that weather conditions may be the other factor. It is possible that activity of microorganisms and also perhaps activity of plant roots were limited in the first season, which was the period from October to December, due to low air temperature and rainfall. When the weather conditions became more favorable in the second season, which was the period from February to April, microorganisms may have become more active producing organic acids and $\mathrm{CO}_{2}$ from organic materials and root exudates and, in turn, lowering $\mathrm{pH}$ of surrounding soil environment that leads to solubilization of $\mathrm{Ca}$ and $\mathrm{Mg}$ from carbonates which are present in high level in the test soil. Nevertheless, vermicompost appeared to be more effective to increase exchangeable $\mathrm{Ca}$ and $\mathrm{Mg}$ contents of soils when the vermicompost and farmyard manure applied in the same doses are compared with each other. This result is in agreement with the observation previously reported (Azarmi et al., 2008).

\section{Electrical Conductivity (EC) and $p H$}

Changes that occurred in $\mathrm{pH}$ in blocks receiving vermicompost and farmyard manure at the rates of $40 \mathrm{tha}^{-1}$ during the first and second growth seasons are given in Fig. 2 . In the first and second seasons, soil $\mathrm{pH}$ values of all treatments followed similar trend in the first three-four weeks. After the third and fourth week, however, $\mathrm{pH}$ values of soils receiving organic materials (FM and V) began to decrease and remained lower than the control and CF treatments during the remainder of the growth periods. Farmyard manure appeared to decrease soil $\mathrm{pH}$ more than vermicompost and difference among treatments was found to be statistically significant $(\mathrm{p}<0.001)$ (Table 4). Effect of treatment $\times$ time interaction on soil $\mathrm{pH}$ was also significant
( $p<0.001$ and $p<0.05$ for the first and second seasons, respectively).

Even though EC values of soils fluctuated during the both growth seasons depending on time and treatment, organic and chemical amendments generally showed increasing trend compared to the control (Fig. 3). In the first season, the highest EC value was recorded with CF treatment and overall difference among treatments was significant based on calculated mean values $(p<0.001)$ (Table 4). In the second season, the highest values were observed with FM20, FM40, and V40 treatments in the first week of the experiment. Later in the growth season, however, CF treatment increased the soil EC more than did other treatments. Based on calculated mean values, overall difference among treatments was significant also in the second season $(\mathrm{p}<0.001)$. Effect of treatment $x$ time interaction was found to be significant in both growth seasons $(\mathrm{p}<0.001)$.

Plant growth, availability of nutrients, and microbial activity in soil are greatly influenced by soil $\mathrm{pH}$. For many agriculturally important plants including celery, optimum soil $\mathrm{pH}$ value ranges from 6 to 7 (Hartel, 2005). In the present study, vermicompost and farmyard manure decreased the soil $\mathrm{pH}$ to optimum levels even though test soil has alkaline $\mathrm{pH}$ and high lime content, and organic fertilizers initially have alkaline reaction (Table 2). Previously published studies also indicate that organic amendments can lower soil pH (Khaleel et al., 1981; Atiyeh et al., 2001). The relatively lower $\mathrm{pH}$ in soils treated with organic fertilizers can be attributed to organic acids produced through degradation of organic compounds added with organic fertilizers and $\mathrm{CO}_{2}$ originated from higher root and microbial activity leading to $\mathrm{H}_{2} \mathrm{CO}_{3}$ formation (Brady and Weil, 2001). It is known that organic and chemical fertilizers elevate soil EC and our study
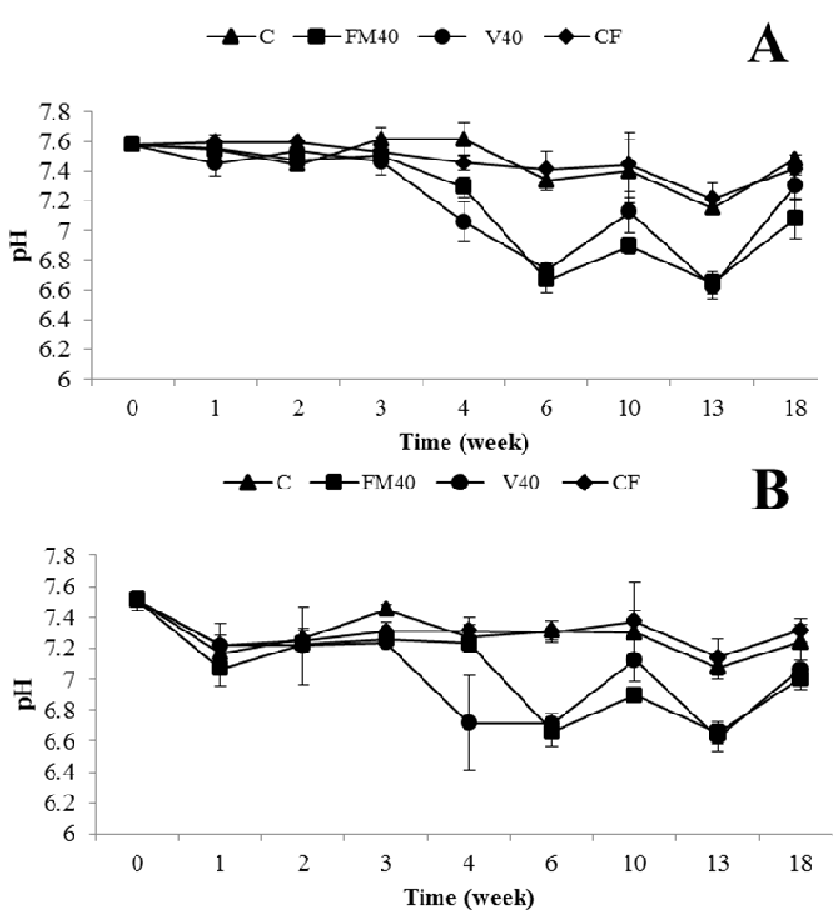

Fig. 2. Changes in $\mathrm{pH}$ in soils during the first $(\mathrm{A})$ and second (B) growth season with farmyard manure (FM40) and vermicompost (V40) applied at the rate of $40 \mathrm{t} \mathrm{ha}^{-1}$, chemical fertilizer (CF), and control (C) treatments. Error bars represent standard errors based on four replicates. 
Table 4. Effect of treatments on $\mathrm{pH}, \mathrm{EC}$, enzyme activity and number of bacteria in soil during growth seasons

\begin{tabular}{|c|c|c|c|c|c|c|c|c|c|c|c|c|}
\hline \multirow{3}{*}{ Treatment } & \multicolumn{2}{|c|}{$\mathrm{pH}$} & \multicolumn{2}{|c|}{$\begin{array}{c}\text { EC } \\
\left(\mu \mathrm{S} \mathrm{cm}^{-1}\right)\end{array}$} & \multicolumn{2}{|c|}{$\begin{array}{c}\text { Urease } \\
\left(\mu \mathrm{g} \mathrm{NH} 4_{4}^{+}-\mathrm{Ng}^{-1} \mathrm{dw} \mathrm{h}^{-1}\right)\end{array}$} & \multicolumn{2}{|c|}{$\begin{array}{l}\text { Alkaline phosphatase } \\
\left(\mu \mathrm{g} \text { PNP g-1 } \mathrm{dw} \mathrm{h}^{-1}\right)\end{array}$} & \multicolumn{2}{|c|}{$\begin{array}{c}\beta \text {-glucosidase } \\
\left(\mu \mathrm{g} \mathrm{PNG} \mathrm{g}^{-1} \mathrm{dw} \mathrm{h}^{-1}\right) \\
\end{array}$} & \multicolumn{2}{|c|}{$\begin{array}{c}\text { Number of bacteria } \\
\left(10^{6} \mathrm{cfu}^{-1} \mathrm{dw}\right)\end{array}$} \\
\hline & \multicolumn{12}{|c|}{ Growth Season } \\
\hline & I & II & I & II & I & II & I & II & I & II & I & II \\
\hline $\mathrm{C}$ & $7.46 a^{1}$ & $7.28 \mathrm{a}$ & $252.98 \mathrm{~d}$ & $227.58 \mathrm{~d}$ & $28.67 \mathrm{~b}$ & $30.29 c$ & $25.71 \mathrm{~b}$ & $25.94 \mathrm{~d}$ & $8.69 c$ & $9.59 c$ & $0.90 \mathrm{c}$ & $1.86 \mathrm{~d}$ \\
\hline FM20 & $7.20 c$ & $7.09 \mathrm{~b}$ & $303.52 \mathrm{~cd}$ & $333.04 \mathrm{bc}$ & $53.13 \mathrm{a}$ & $53.21 \mathrm{~b}$ & $38.00 \mathrm{a}$ & $41.89 \mathrm{c}$ & $11.73 \mathrm{a}$ & $15.04 \mathrm{~b}$ & $2.29 \mathrm{a}$ & $2.99 \mathrm{bc}$ \\
\hline V20 & $7.30 \mathrm{~b}$ & $7.20 \mathrm{a}$ & $325.72 \mathrm{~cd}$ & $303.51 \mathrm{c}$ & $53.95 \mathrm{a}$ & $55.69 \mathrm{~b}$ & $34.14 \mathrm{a}$ & $47.33 b c$ & $10.94 \mathrm{ab}$ & $16.07 \mathrm{~b}$ & $1.54 \mathrm{~b}$ & $2.62 \mathrm{c}$ \\
\hline FM40 & $7.18 \mathrm{c}$ & $7.05 \mathrm{~b}$ & $475.73 \mathrm{~b}$ & $368.75 b c$ & $54.87 \mathrm{a}$ & $60.78 \mathrm{a}$ & $38.82 \mathrm{a}$ & $50.36 \mathrm{~b}$ & $12.27 \mathrm{a}$ & $16.39 \mathrm{ab}$ & $2.07 \mathrm{a}$ & $3.82 \mathrm{a}$ \\
\hline V40 & $7.20 c$ & $7.04 \mathrm{~b}$ & $366.30 c$ & $384.84 \mathrm{~b}$ & $56.44 \mathrm{a}$ & $61.40 \mathrm{a}$ & $34.65 \mathrm{a}$ & $61.13 \mathrm{a}$ & $12.33 \mathrm{a}$ & $17.94 \mathrm{a}$ & $1.98 \mathrm{ab}$ & $3.38 \mathrm{ab}$ \\
\hline $\mathrm{CF}$ & $7.47 \mathrm{a}$ & $7.30 \mathrm{a}$ & $574.35 \mathrm{a}$ & $458.81 \mathrm{a}$ & $31.54 \mathrm{~b}$ & $32.17 \mathrm{c}$ & $27.43 \mathrm{~b}$ & $29.37 \mathrm{~d}$ & $9.34 b c$ & $10.67 \mathrm{c}$ & $1.01 \mathrm{c}$ & $2.02 \mathrm{~d}$ \\
\hline \multicolumn{13}{|c|}{ ANOVA (LSD 5\%) } \\
\hline Time & $42.22^{* * * 2}$ & $17.01^{* * *}$ & $7.00^{* * *}$ & $11.75^{* * *}$ & $378.35^{* * *}$ & $160.41^{* * *}$ & $38.39^{* * *}$ & $19.14^{* * *}$ & $76.15^{* * *}$ & $50.23^{* * *}$ & $9.08^{* * *}$ & $9.99^{* * *}$ \\
\hline Treatment & $16.75^{* * *}$ & $10.10^{* * *}$ & $16.29^{* * *}$ & $16.72^{* * *}$ & $259.75^{* * *}$ & $217.31^{* * *}$ & $7.10^{* * *}$ & $33.24^{* * *}$ & $9.73^{* * *}$ & $45.01^{* * *}$ & $10.14^{* * *}$ & $17.67^{* * *}$ \\
\hline $\begin{array}{c}\text { Time } \times \\
\text { Treatment }\end{array}$ & $2.60^{* * *}$ & $1.63^{*}$ & $3.04^{* * *}$ & $2.73^{* * *}$ & $25.87^{* * *}$ & $12.23^{* * *}$ & $2.97^{* * *}$ & $2.84^{* * *}$ & $5.30^{* * *}$ & $3.72^{* * *}$ & $1.89^{* * 3}$ & $1.52^{* 4}$ \\
\hline
\end{tabular}

Means in the same column followed by the same letter are not significantly different.

$2 * * * \mathrm{p}<0.001$.

${ }^{3 * *} \mathrm{p}<0.01$.

${ }^{4 *} \mathrm{p}<0.05$.
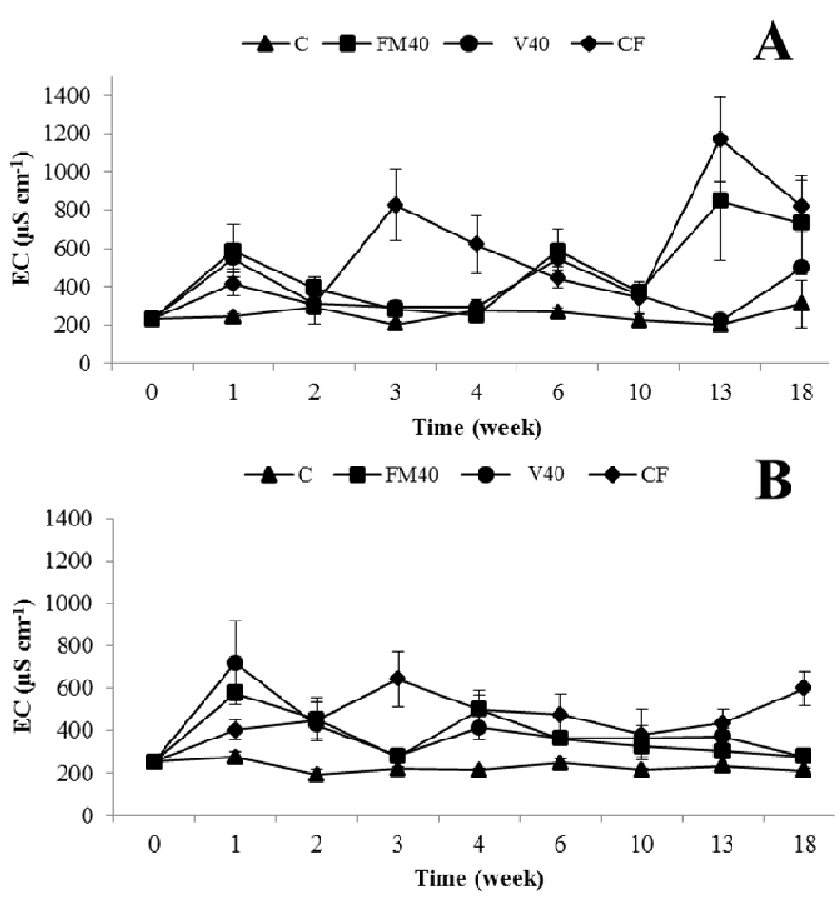

Fig. 3. Changes in EC in soils during the first (A) and second (B) growth season with farmyard manure (FM40) and vermicompost (V40) applied at the rate of $40 \mathrm{t} \mathrm{ha}^{-1}$, chemical fertilizer (CF), and control (C) treatments. Error bars represent standard errors based on four replicates.

showed an increase in EC with farmyard manure and vermicompost applied in increasing doses. However, overall evaluation indicated that $\mathrm{EC}$ values of soils treated with organic fertilizers were below the EC value of soil with chemical fertilizer. This is possibly due to the fact that, unlike chemical fertilizers, organic fertilizers release nutrients more gradually as a result of degradation process and their chelate effect (Gerke et al., 1999; Sharma and Banik, 2014). EC values of vermicompost-treated soils (except for V4 in the second season) were generally similar to or slightly below those of soils with farmyard manure applied in the same doses. This finding is supported by the reports pointing out the advantage of vermicompost over other organic fertilizers due to more gradual release of nutrients from vermicompost than from any other organic fertilizer to the soil environment (Kale et al., 1987; Nethra et al., 1999; Lazcano et al., 2008). With exception of one or two sampling points, EC of soils with vermicompost and farmyard manure followed similar trend during both growth seasons. EC values obtained in the current study were not in a level to cause any salinity problem. Several researchers pointed out that organic fertilizers do not cause salinity when applied in moderate levels(Sutton, 1994; Garg et al., 2009).

\section{Urease activity}

In the first growth season, urease activity showed increasing trend in all treatments during the first four weeks. During this time, organic and chemical amendments exhibited significantly higher urease activity than the control. After the fourth week, however, the activity in the control and chemical fertilizer treatments became similar and stable while the activity in organic amendments continued to rise (Fig. 4). Overall difference between organic amendments and the control and chemical fertilizers was found to be statistically significant $(p<0.001)$ and urease activity appeared to be significantly affected by the treatment $\times$ time interaction $(\mathrm{p}<0.001)($ Table 4). However, there was no significant difference between vermicompost and farmyard manure in all application doses based on calculated mean values. Almost the similar trend in urease activity was observed in the second growth season (Fig. 4). Overall difference among treatments and effect of the treatment $\times$ time interaction was significant $(\mathrm{p}<0.001)$ while no significant difference was found between organic materials applied in the same doses (Table 4).

Due to its involvement in nitrogen cycle, urease is considered to be one of the important enzymes that are used as indicators to monitor soil fertility. Its activity is known to be increased with stimulation of microorganisms in soil (Bremner and Mulvaney, 1982; Dick and Tabatabai, 1993; Bandick and Dick, 1999). In the present study, vermicompost and farmyard manure applications elevated soil urease activity compared to the chemical fertilizer and the control treatments. This result is consistent with findings of previous studies (Gopinath et al., 2009; Sharma and Banik, 2014) and can be attributed to the addition of nutrients in organic forms, including nitrogenous compounds, to soil through organic materials leading to higher microbial number and activity. However, urease activity in soils treated with vermicompost and 
286
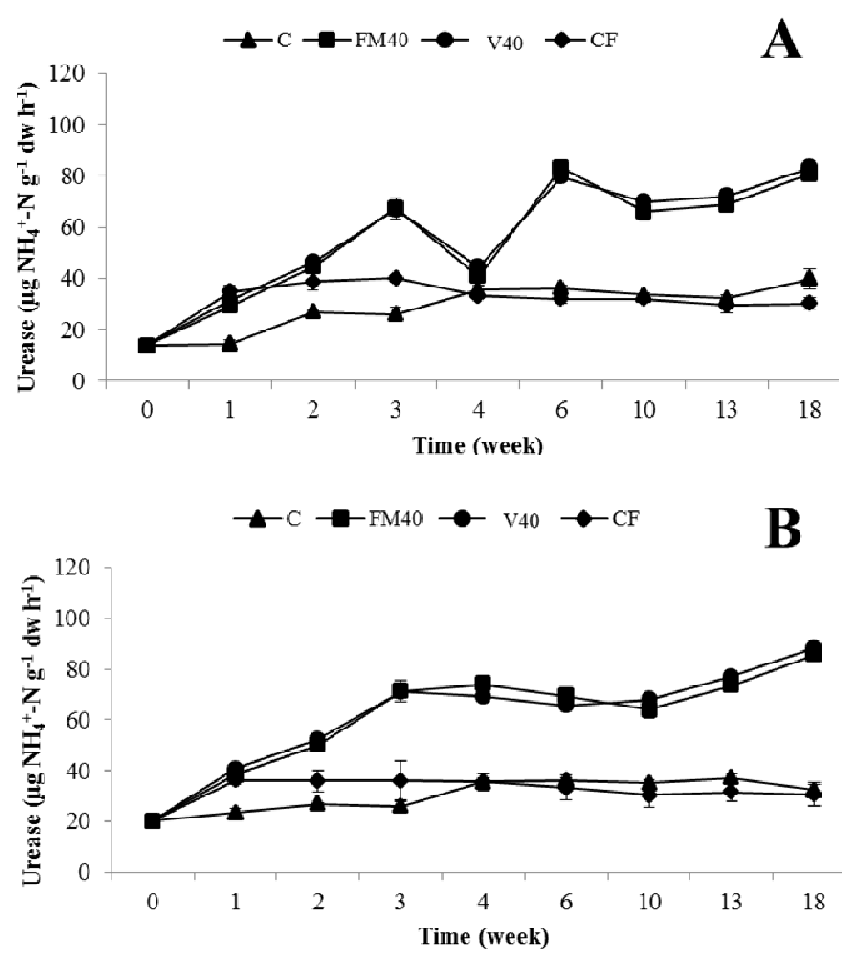

Fig. 4. Changes in urease activity in soils during the first (A) and second (B) growth season with farmyard manure (FM40) and vermicompost (V40) applied at the rate of $40 \mathrm{t} \mathrm{ha}{ }^{-1}$, chemical fertilizer (CF), and control (C) treatments. Error bars represent standard errors based on four replicates.

farmyard manure followed similar trend during the both growth seasons and no significant difference was observed between these organic materials applied in the same doses. In their study, Sajjad et al. (2002) found that soil urease activity maintain a certain stable level and may not depend on type of organic material due to its complexation with humus compounds in soil, and stabilization and protection of the enzyme by organic matter. Similar urease activities observed between organic fertilizers in our study may be attributed to this fact. On the other hand, Albiach et al., (2000) stated that soil urease activity is associated with urea and urea-like compounds found in organic fertilizers. It is also possible that the vermicompost and farmyard manure used in the present study include similar amount of urea and urea-like compounds.

\section{Alkaline phosphatase activity}

In the first growth season, alkaline phosphatase activity of soils amended with vermicompost and farmyard manure was higher than those with chemical fertilizer and the control during the first three-four weeks (Fig. 5). Farmyard manure appeared to increase the enzyme activity more compared to vermicompost (only in the second week). After the fourth week, however, the enzyme activity in organic treatments dropped to a level similar to chemical fertilizer and control treatments and generally remained stable. Overall difference among treatments was significant $(p<0.001)$ (Table 4). Treatment $\times$ time interaction was also statistically significant $(p<0.001)$. On the other hand, no significant difference was found between vermicompost and farmyard manure in all application doses. In the second growth season, from the beginning of the experiment, organic material-amended soils had higher
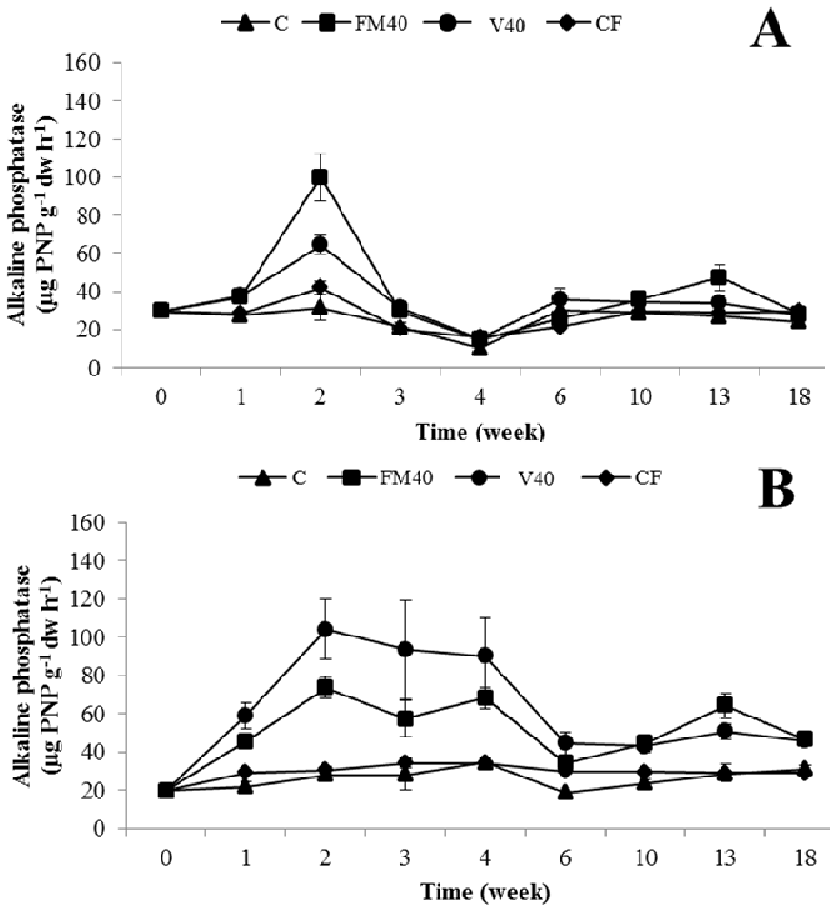

Fig. 5. Changes in alkaline phosphatase activity in soils during the first (A) and second (B) growth season with farmyard manure (FM40) and vermicompost (V40) applied at the rate of $40 \mathrm{t} \mathrm{ha}^{-1}$, chemical fertilizer (CF), and control (C) treatments. Error bars represent standard errors based on four replicates.

alkaline phosphatase activity compared to chemical fertilizers and control treatments (Fig. 5) and remained higher during this growth season. Based on calculated mean values, vermicompost and farmyard manure resulted in significantly higher alkaline phosphatase activity compared to chemical fertilizer and the control $(\mathrm{p}<0.001)$ (Table 4). Difference between vermicompost and farmyard manure treatments was also significant and vermicompost increased the enzyme activity more effectively than farmyard manure applied in the same doses (Fig. 5, Table 4). Effect of treatment $\times$ time interaction was also found to be significant $(\mathrm{p}<0.001)$.

It is known that soil alkaline phosphatase activity is stimulated by phosphorus bound to organic compound supplied with organic fertilizers (Kanchikerimath and Singh, 2001). Therefore, it is not surprising to observe relatively higher phosphatase activity in vermicompost and farmyard manure treatments compared to chemical fertilizer and control treatments. This observation is also in agreement with previous studies reporting that organic fertilizers including vermicompost increase this enzyme's activity in soil (Saha et al., 2008; Doan et al., 2013). Significantly higher soil phosphatase activity with vermicompost than with farmyard manure in the second growth season, but not in the first growth season, indicates that, in more favorable weather conditions, vermicompost has higher potential to stimulate indigenous organisms to produce this enzyme in the test soil.

\section{$\beta$-Glucosidase activity}

In the first growth season, overall difference between treatments was found to be significant $(p<0.001)$ (Table 4). However, with one exception, there was no significant difference 
between organic fertilizers and also application doses. Effect of treatment $\times$ time interaction was significant $(p<0.001)$. Soil $\beta$ glucosidase activity in all treatments fluctuated but generally followed similar trend during this season. In the second growth season, however, difference among treatments was more apparent $(\mathrm{p}<0.001)$ (Table 4 and Fig. 6). Based on calculated mean values, overall difference between vermicompost and farmyard manure was not significant when applied at the rate of $20 \mathrm{tha}^{-1}$ (V20 and FM20) but was significant when the application dose was increased to $40 \mathrm{t} \mathrm{ha}^{-1}$ (V40 and FM40) (Table 4). However, when the sampling points were evaluated individually vermicompost appeared to increase soil $\beta$-glucosidase activity more effectively especially during the period between the second and sixth week (Fig. 6) and effect of treatment $x$ time interaction was found to be significant in this season $(p<0.001)$.

Activity of $\beta$-glucosidase can be used to assess carbon turnover that has an impact on soil fertility due to the fact that it involves in degradation of cellulose, an important process producing glucose which is one of the main energy sources for soil organisms. Several scientists indicated that addition of organic fertilizers increases soil $\beta$-glucosidase activity depending on their composition of carbon compounds (Albiach et al., 2000; Laic et al., 2002; Srivastava et al., 2012). Indeed, in the present study, vermicompost and farmyard manure treatments showed higher enzyme activity compared to the other treatments and these results are in consistent with previous reports. Higher $\beta$-glucosidase activity in soils with vermicompost than with farmyard manure in the second growth season suggests that, under favorable conditions for soil microorganisms, vermicompost has greater potential to stimulate organisms capable of secretion of $\beta$-glucosidase. This can be
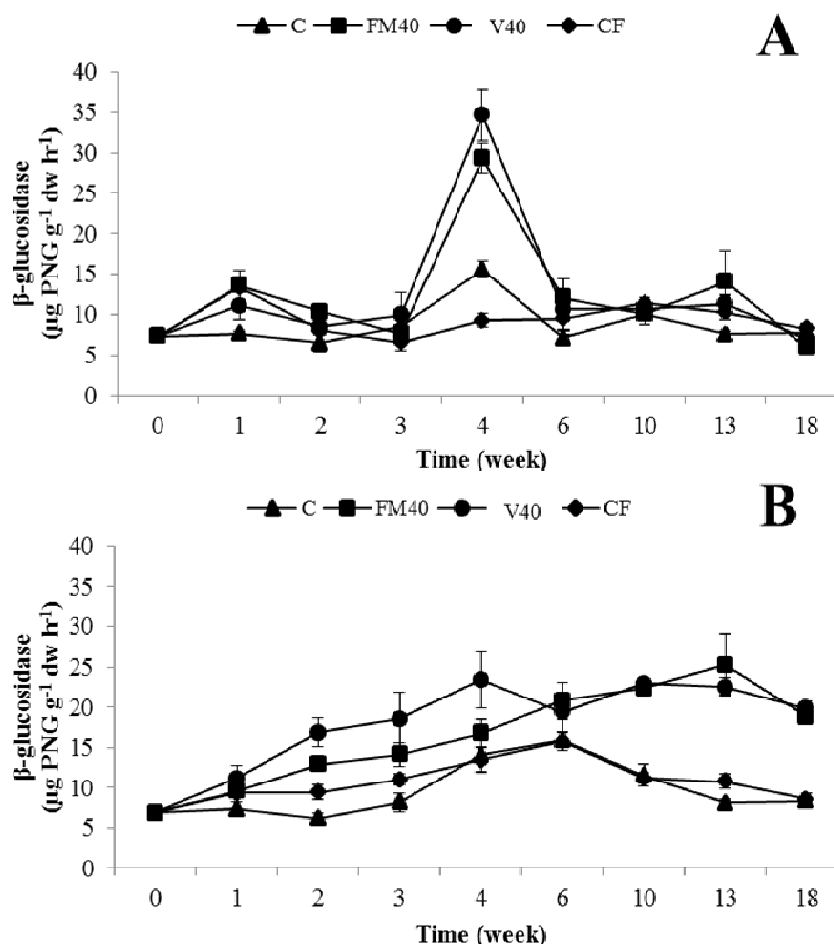

Fig. 6. Changes in $\beta$-glucosidase activity in soils during the first (A) and second (B) growth season with farmyard manure (FM40) and vermicompost (V40) applied at the rate of $40 \mathrm{t}$ ha${ }^{1}$, chemical fertilizer (CF), and control (C) treatments. Error bars represent standard errors based on four replicates. attributed to the fact that vermicompost contain carbon compounds with relatively simple structure, such as cellobiose and glucose, as indicated previously (Parthasarathi and Ranganathan, 2000; Gopinath et al., 2008).

\section{Number of total aerobicmesophilic bacteria}

Aerobic mesophilic bacterial numbers in treatment soils are given in Fig. 7. Based on the calculated mean values, in both growth seasons, application of organic fertilizers resulted in higher bacterial number than did chemical fertilizer and control $(\mathrm{p}<0.001)$. In addition, farmyard manure appeared to yield slightly but significantly higher bacterial number in soil compared to vermicompost applied in the same doses $(p<0.001)$ (Table 4). Effect of treatment $x$ time interaction was also significant in both growth season $(\mathrm{p}<0.01$ and $\mathrm{p}<0.05$, respectively).

Organic compounds supplied by organic materials are the major source of nutrients for soil microorganisms. Therefore, soil microorganisms are considered one of the major factors determining soil fertility through their involvement, especially, in transformation of nutrients that is important for plants. In the present study, farmyard manure applications appeared to give higher aerobic mesophilic bacterial number than did vermicompost even though the difference was less than 10-fold. This result contradicts a previous study conducted in a similar soil with no plants under greenhouse conditions in the same region ( $\mathrm{Uz}$ and Tavali, 2014). One of the possible explanations is that, farmyard manure contains microorganisms that are more adaptive and supports indigenous microorganisms that respond better under the field conditions with the presence of test plant. Since the farmyard manure and vermicompost have similar bacterial
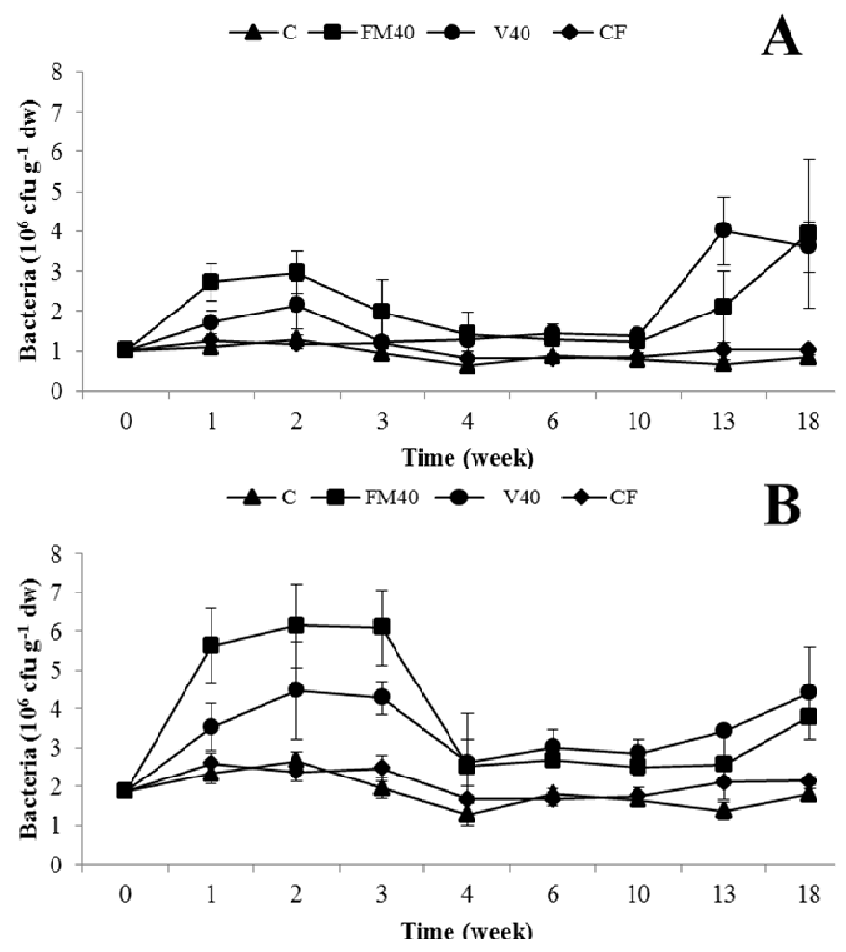

Fig. 7. Changes in number of aerobic mesophilic bacteria in soils during the first $(\mathrm{A})$ and second $(\mathrm{B})$ growth season with farmyard manure (FM40) and vermicompost (V40) applied at the rate of $40 \mathrm{t}$ ha $^{-1}$, chemical fertilizer (CF), and control (C) treatments. Error bars represent standard errors based on four replicates. 
288

numbers (Table 2), the difference may be attributed to type of bacteria present in the farmyard manure and farmyard manure's effect on soil microbial diversity. On the other hand, this does not necessarily mean that vermicompost is less effective on soil microbial activity and diversity. Several scientists reported greater microbial activity and diversity in vermicompost and soils amended with vermicompost (Kannan et al., 2005; Aira et al., 2008; Sebastian et al., 2009; Doan et al., 2013). In the present study, higher alkaline phosphatase and $\beta$-glucosidase activities in vermicompost-treated soils are also indicatives of vermicompost's influence on microbial activity. Therefore, an alternative and perhaps the most likely explanation is that some of the bacterial species in soils treated with vermicompost could not grow in the growth media used in the enumeration procedure leading to underestimation of bacterial populations. This result indicate that, in order to understand vermicompost's effect on microbial dynamics of soil, more detailed studies targeting specific microbial groups should be conducted.

\section{Conclusion}

The aim of this study was to investigate effect of vermicompost on some chemical and biological properties of alkaline soil with high lime content during celery production in two consecutive growth periods under the open field conditions in the semiarid Mediterranean region of Turkey. The result showed that vermicompost significantly affects chemical and biological properties of alkaline soil with high lime content during celery production under field conditions. In general, organic matter, total $\mathrm{N}$, available $\mathrm{P}$, and exchangeable $\mathrm{Ca}$ contents of soil were higher with vermicompost than with farmyard manure. Especially in the second growth season, when weather conditions are more favorable, vermicompost has higher potential to stimulate microorganism involved in carbon and phosphorus cycles. This may also be an evidence for its cumulative effect on soil microorganisms. However, compared to farmyard manure, vermicompost appeared to support slightly lower bacterial number in this soil. Clearly, vermicompost has a high potential to be used as an organic fertilizer during celery production in agricultural systems in the Mediterranean region of Turkey, whose soils are typically in alkaline character and have high lime content. However, in order to assess its full potential and its long-term effects in the region, further studies are required with other plants and various production practices.

\section{Acknowledgments}

This study was financially supported by the Scientific Research Projects Coordination Unit of Akdeniz University (Grant no. 2011.01.0104.005).

\section{References}

Agarwal S (1999). Study of vermicomposting of domestic waste and the effects of vermicompost on growth of some vegetable crops. PhD Thesis. University of Rajasthan,Jaipur,India.

Aira M, Lazcano C, Dominguez J (2008). Earthworms trigger enzymatic activities through the increase of microbial biomass and activity during vermicomposting of pig slurry, compost and digestate: Sustainability, benefits, impact for the environment and for plant production. In: Proceedings of the CODIS. Switzerland pp 285-288.
Albiach R, Canet R, Pomares F, Ingelmo F (2000). Microbial biomass content and enzymatic activities after the application of organic amendments to a horticultural soil. Bioresource Technology 75:43-48.

Arancon NQ, Edwards CA, Bierman P (2006). Influences of vermicomposts on field strawberries: Part 2. Effects on soil microbiological and chemical properties. Bioresource Technology 97:831-840.

Arancon NQ, Edwards CA, Bierman P, Metzger JD, Lee S, Welch C (2003). Effects of vermicomposts on growth and marketable fruits of field-grown tomatoes, peppers and strawberries. Pedobiologia 47:731735.

Atiyeh RM, Edwards CA, Subler S, Metzger JD (2001). Pig manure vermicompost as a component of a horticultural bedding plant medium: effects on physicochemical properties and plant growth. Bioresource Technology 78:11-20.

Azarmi R, Gigou MT, Taleshmikail RD (2008). Influence of vermicompost on soil chemical and physical properties in tomato (Lycopersicum esculentum) field. African Journal of Biotechnology 7:2397-2401.

Bandick AK, Dick RP (1999). Field management effects on soil enzyme activities. Soil Biology and Biochemistry 31:1471-1479.

Bouyoucos GJ (1951). A recalibration of hydrometer method for making mechanical analysis of soils. Agronomy Journal 43:434 438.

Brady NC, Weil RR (2001). The nature and properties of soils. Prentice Hall (13thed).NJ,USA.

Bremner JM, Mulvaney CS (1982). Nitrogen-Total. In: Page AL, Miller RH, Keeney DR (Eds). Methods of soil analysis: Part 2-Chemical and microbiological properties. Soil Science Society of America Inc, Madison, Wisconsin, USA pp 595-622.

Caglar KO (1949). Toprak bilgisi [Soil science]. Ankara Üniversitesi Ziraat Fakültesi, Ankara, Turkey.

Carr EA, Nelson EB (2014). Disease-suppressive vermicompost induces a shift in germination mode of Pythium aphanidermatum Zoosporangia. PlantDisease 98:361-367.

Cheng WX, Johnson DW, Fu SL (2003). Rhizosphere effects on decomposition: Controls of plant species, phenology, and fertilization. Soil Science Society of America Journal 67:1418-1427.

Dick WA, Tabatabai MA (1993). Significance and potential uses of soil enzymes. In: Metting FB (Ed). Soil microbial ecology: Applications in agricultural and environmental management. CRC Press, New York pp95-127.

Doan TT, Bouvier C, Bettarel Y, Bouvier T, Henry-des-Tureaux T, Janeau JL, Lamballe P, Nguyen BV, Jouquet P (2014). Influence of buffalo manure, compost, vermicompost and biochar amendments on bacterial and viral communities in soil and adjacent aquatic systems. Applied Soil Ecology 73:78-86.

Doan TT, Jusselme DM, Lata JC, Nguyen BV, Jouquet P (2013). The earthworm species Metaphire posthuma modulates the effect of organic amendments (compost vs. vermicompost from buffalo manure) on soil microbial properties: A laboratory experiment. European Journal of Soil Biology 59:15-21. 
Doube BM, Brown GG (1998). Life in a complex community: Functional interactions between earthworms, organic matter, microorganisms, and plants. In: Edwards C (Ed). Earthworm ecology.St Lucie Press, London pp 179-211.

Ersahin YS, Haktanir K, Yanar Y (2009). Vermicompost suppresses Rhizoctonia solani Kuhn in cucumber seedlings. Journal of Plant Diseases and Protection 116:182-188.

Ferreras L, Gomez E, Toresani S, Firpo I, Rotondo R (2006). Effect of organic amendments on some physical, chemical and biological properties in a horticultural soil. Bioresource Technology 97:635-640.

Garg VK, Gupta R, Kaushik P (2009). Vermicomposting of solid textile mill sludge spiked with cow dung and horse dung: A pilot-scale study. International Journal of Environment and Pollution 38:385-396.

Gerke HH, Arning M, Stoppler-Zimmer H (1999). Modeling long-term compost application effects on nitrate leaching. Plant and Soil 213:7592.

Gopinath KA, Saha S, Mina BL (2011). Effects of organic amendments on productivity and profitability of bell pepper-french bean-garden pea system and on soil properties during transition to organic production. Communications in Soil Science and Plant Analysis 42:2572-2585.

Gopinath KA, Saha S, Mina BL, Pande H, Kundu S, Gupta HS (2008). Influence of organic amendments on growth, yield and quality of wheat and on soil properties during transition to organic production. Nutrient Cycling in Agroecosystems 82:51-60.

Gopinath KA, SahaS, Mina BL, Pande H, Srivastva AK, Gupta HS (2009). Bell pepper yield and soil properties during conversion from conventional to organic production in Indian Himalayas. Scientia Horticulturae 122:339-345.

Hartel PG (2005). The soil habitat. In: Sylvia DM, Fuhrmann JJ, Hartel PG, Zuberer DA (Eds). Principles and application of soil microbiology. Pearson Education Inc, Saddle Rivers, New Jersey, USA pp 26-53.

Herencia JF, Ruiz-Porras JC, Melero S, Garcia-Galavis PA, Morillo E, Maqueda C (2007). Comparison between organic and mineral fertilization for soil fertility levels, crop macronutrient concentrations, and yield. Agronomy Journal 99:973-983.

Jackson ML (1970). Soil chemical analysis. Parallel Press (2nd ed), Madison, Wisconsin.

Jenkinson DS (1990). The turnover of organic-carbon and nitrogen in soil. Philosophical Transactions of the Royal Society of London Series BBiological Sciences 329:361-368.

Johnston AE (1997). The value of long-term field experiments in agricultural, ecological, and environmental research. Advances in Agronomy 59:291-333.

Kacar B (1994). Bitki ve toprağn kimyasal analizleri. III. Toprak analizleri [Chemical analysis of plant and soil. III. Soil analysis]. Ankara Üniversitesi Ziraat Fakültesi Eğitim Araştırma ve Geliştirme Vakfi Yayınlar, Ankara, Turkey.

KalantariS, Ardalan MM, Alikhani HA, Shorafa M (2011). Comparison of compost and vermicompost of yard leaf manure and inorganic fertilizer on yield of corn. Communications in Soil Science and Plant Analysis 42:123-131.
Kale RD, Bano K, Sreenivasa MN, Vinayak K, Bagyaraj DJ (1987). Incidence of cellulolytic and lignolytic organisms in the earthworm worked soils. In: Julka JM (Ed). Eartworm resources and vermiculture. Oxford University Press, New Delhi, Indiapp 49-53.

Kanchikerimath M, Singh D (2001). Soil organic matter and biological properties after 26 years of maize - wheat - cowpea cropping as affected by manure and fertilization in a Cambisol in semiarid region of India. Agriculture, Ecosystems and Environment 86:155-162.

Kannan P, Saravanan A, Krishnakumar S, Natarajan SK (2005). Biological properties of soil as influenced by different organic manures. Research Journal of Agriculture and Biological Sciences 1:181-183.

Khaleel R, Reddy KR, Overcash MR (1981). Changes in soil physical properties due to organic waste applications: A review. Journal of Environmental Quality 10:133-141.

KucukyumukZ, Gultekin M, Erdal I (2014). Effects of vermicompost and mycorrhiza on plant growth and mineral nutrition in pepper. Suleyman Demirel UniversitesiZiraat Fakultesi Dergisi 9:51-58.

Laic CM, Liu KL, Jeng GL, Helen W (2002). Effects of fertilization management on soil enzyme activities related to the $\mathrm{C}, \mathrm{N}, \mathrm{P}$ and $\mathrm{S}$ cycles in soils. In: Proceedings of the Transactions of the 12th World Congress of Soil Science. Thailand pp 1382-1389.

Lazcano C, Gomez-Brandon M, Dominguez J (2008). Comparison of the effectiveness of composting and vermicomposting for the biological stabilization of cattle manure. Chemosphere 72:1013-1019.

Lazcano C, Gomez-Brandon M, Revilla P, DominguezJ (2013). Short-term effects of organic and inorganic fertilizers on soil microbial community structure and function. Biology and Fertility ofSoils 49:723-733.

Lindsay WL, Norvell WA (1978). Development of a DTPA soil test for zinc, iron, manganese, and copper. Soil Science Society of America Journal 42:421-428.

Logsdon G (1994). Worldwide progress in vermicomposting. Biocycle 35:63-65.

Nelson DW, Sommers LE (1982). Total carbon, organic carbon, and organic matter. In: Page AL, Miller RH, Keeney DR(Eds). Methods of soil analysis: Part 2- Chemical and microbiological properties. Soil ScienceSociety of America Inc, Madison, Wisconsin, USA pp 539-579.

Nethra NN, Jayaprasad KV, Kale RD (1999). China aster [Callistephus chinensis $(\mathrm{L})]$ cultivation using vermicompost as organic amendment. Crop Research (Hisar) 17:209-215.

Olsen SR, Sommers LE (1982). Phosphorus. In: Page AL, Miller RH, Keeney DR (Eds). Methods of soil analysis: Part 2- Chemical and microbiological properties. Soil Science Society of America Inc, Madison, Wisconsin, USA pp 403-427.

Ouda BA, Mahadeen AY (2008). Effect of fertilizers on growth, yield, yield components, quality and certain nutrient contents in broccoli (Brassica oleracea). International Journal of Agriculture and Biology 10:627-632.

Pant A, Radovich TJK, Hue NV, Arancon NQ (2011). Effects of vermicompost tea (aqueous extract) on Pak Choi yield, quality, and on soil biological properties. Compost Science and Utilization 19:279-292.

Parkinson D, Gray TRC, Williams ST (1971). Methods for studying the ecology of soil microorganisms. Blackwell Science Press (19th ed), Oxford. 
290

Parthasarathi K, Ranganathan LS (2000). Aging effect on enzyme activities in pressmud vermicasts of Lampito mauritii (Kinberg) and Eudrilus engeniae (Kinberg). Biology and Fertility ofSoils30:347-350.

Patil SL, Sheelavantar MN (2006). Soil water conservation and yield of winter sorghum (Sorghum bicolor L. Moench) as influenced by tillage, organic materials and nitrogen fertilizer in semi-arid tropical India. Soil and Tillage Research 89:246-257.

RhoadesJD (1982).Soluble salts. In: Page AL, Miller RH, Keeney DR(Eds). Methods of soil analysis: Part 2- Chemical and microbiological properties. Soil Science Society of America Inc, Madison, Wisconsin, USA pp 167-179.

Saha S, Mina BL, Gopinath KA, Kundu S, Gupta HS (2008). Relative changes in phosphatase activities as influenced by source and application rate of organic composts in field crops. Bioresource Technology 99:1750-1757.

Sajjad MH, Lodhi A, Azam F (2002). Changes in enzyme activity during the decomposition of plant residues in soil. Pakistan Journal of Biological Sciences 5:952-955.

Sallaku G, Babaj I, Kaciu S, Balliu A (2009). The influence of vermicompost on plant growth characteristics of cucumber (Cucumis sativus L.) seedlings under saline conditions. Journal of Food Agriculture and Environment 7:869-872.

Sebastian SP, Udayasoorian C, Jayabalakrishnan RM, Parameswari E (2009). Improving soil microbial biomass and enzyme activities by amendments under poor quality irrigation water. World Applied Sciences Journal 7:885-890.

Sharma RC, Banik P (2014). Vermicompost and fertilizer application: Effect on productivity and profitability of baby corn (Zea Mays L) and soil health. Compost Science and Utilization 22:83-92.

Singh R, Soni SK, Awasthi A, Kalra A (2012). Evaluation of vermicompost doses for management of root-rot disease complex in Coleus forskoblii under organic field conditions. Australasian Plant Pathology 41:397403.

Soltanpour PN, Workman SM (1981). Use of Inductively - Coupled Plasma Spectroscopy for the simultaneous determination of macro and micro nutrients in $\mathrm{NH}_{4} \mathrm{HCO}_{3}$-DTPA extracts of soils. In: Barnes RM (Ed). Developments in Atomic Plasma Analysis. John Wiley \& Sons Ltd, USA pp 673-680.
Somasekhara YM, Kale RD, Hosmath JA (2011). Effect of culture filtrates of vermicompost against pomegranate (Punica granatum L.) wilt pathogen, Ceratocystis fimbriata Ell. \& Halst. Research on Crops 12:217-221.

SPSS (2008).SPSS Statistics for Windows, version 17.0.SPSS Inc, Chicago, USA.

Srivastava PK, Gupta M, Upadhyay RK, SharmaS, Shikha, Singh N, Tewari $\mathrm{K}$, Singh B (2012). Effects of combined application of vermicompost and mineral fertilizer on the growth of Allium cepa $\mathrm{L}$. and soil fertility. Journal of Plant Nutrition and Soil Science 175:101-107.

Sutton AL (1994). Proper animal manure utilization. Journal of Soil and WaterConservation 49:65-70.

Tabatabai MA (1994).Soil Enzymes. In: Weaver RW (Ed).Methods ofSoil Analysis: Part 2- Microbiological and Biochemical Properties. Soil Science Society of America Inc, Madison, Wisconsin pp 775-833.

Tavali IE, Maltas AS, Uz I, Kaplan M (2013). The effect of vermicompost on yield, quality and nutritional status of cauliflower (Brassica oleracea var. botrytis). Akdeniz UniversitesiZiraat Fakultesi Dergisi 26:115-120.

Tejada M, Benitez C (2011). Organic amendment based on vermicompost and compost: Differences on soil properties and maize yield. Waste Management and Research 29:1185-1196.

Tiwari RC, Sharma PK, Khandelwal SK (2004). Effect of green-manuring through Sesbania cannabina and Sesbania rostrata and nitrogen application through urea to maize (Zea mays) in maize-wheat (Triticum aestivum) cropping system. Indian Journal of Agronomy 49:15-17.

Uz I, Tavali IE (2014). Short-term effect of vermicompost application on biological properties of an alkaline soil with high lime content from Mediterranean region of Turkey. Scientific World Journal doi: $10.1155 / 2014 / 395282$.

Vural H, Esiyok D, Duman I (2000). Kültür sebzeleri (Sebze yetiştirme) [Culture vegetables (Vegetable growing)]. Ege Üniversitesi Ziraat Fakültesi Bahçe Bitkileri Bölümü, Izmir, Turkey.

Zakir HM, Sultana MN, Saha KC (2012). Influence of commercially available organic vs inorganic fertilizers on growth yield and quality of carrot. Journal of Environmental Science and Natural Resources 5:3945. 